\title{
Gamma-radiation-induced ATM-dependent signalling in human T-lymphocyte leukemic cells, MOLT-4
}

\author{
Aleš Tichý1,2凶, Darina Záškodová2, Martina Ǩezáčováe ${ }^{2}$ Jiřina Vávrová ${ }^{1}$ \\ Doris Vokurková ${ }^{3}$, Jaroslav Pejchal ${ }^{1}$, Zdena Vilasová ${ }^{2}$, Jaroslav Cerman ${ }^{2}$ and \\ Jan Österreicher ${ }^{1}$
}

\begin{abstract}
${ }^{1}$ Department of Radiobiology, Faculty of Military Health Sciences in Hradec Králové, University of Defence in Brno, Czech Republic; ${ }^{2}$ Institute of Medical Biochemistry, Faculty of Medicine in Hradec Králové, Charles University in Prague, Czech Republic; ${ }^{3}$ Institute of Clinical Immunology and Allergology, University Hospital Hradec Králové, Czech Republic
\end{abstract}

Received: 16 January, 2007; revised: 21 May, 2007; accepted: 01 June, 2007 available on-line: 12 June, 2007

\begin{abstract}
ATM kinase (ATM) is essential for activation of cell cycle check points and DNA repair in response to ionizing radiation (IR). In this work we studied the molecular mechanisms regulating DNA repair and cell death in human T-lymphocyte leukemic cells, MOLT-4. Apoptosis was evaluated by flow-cytometric detection of annexin V. Early apoptotic cells were determined as subG1 cells and late apoptotic cells were determined as APO2.7-positive ones. Proteins involved in ATM signalling pathway were analysed by Western-blotting. We observed a rapid $(0.5 \mathrm{~h})$ phosphorylation of ATM declining after $6 \mathrm{~h}$ after irradiation by all the doses studied (1.5, 3.0, and 7.5 Gy). Checkpoint kinase-2 (Chk-2) was also phosphorylated after $0.5 \mathrm{~h}$ but its phosphorylated form persisted 4, 2, and $1 \mathrm{~h}$ after the doses of 1.5, 3.0, and 7.5 Gy, respectively. The amount of p53 protein and its form phosphorylated on Ser-392 increased $1 \mathrm{~h}$ after irradiation (1-10 Gy). The lethal dose of $7.5 \mathrm{~Gy}$ caused an immediate induction and phosphorylation of p53 after 0.5 $\mathrm{h}$ post-irradiation. At the time of phosphorylation of p53, we found simultaneous phosphorylation of the oncoprotein Mdm2 on Ser-166. Neither ATM nor its downstream targets showed a dose-dependent response after $1 \mathrm{~h}$ when irradiated by the doses of 1-10 Gy. MOLT-4 cells were very sensitive to the effect of IR. Even low doses, such as $1.5 \mathrm{~Gy}$, induced apoptosis $16 \mathrm{~h}$ after irradiation (evaluated according to the cleavage of nuclear lamin B to a 48-kDa fragment). IR-induced molecular signalling after exposure to all the tested doses was triggered by rapid phosphorylation of ATM and Chk-2. Subsequent induction of p53 protein and its phosphorylation was accompanied by concomitant phosphorylation of its negative regulator, oncoprotein $\mathrm{Mdm} 2$, and followed by induction of apoptosis.
\end{abstract}

Keywords: ATM kinase, checkpoint kinase-2, p53, Mdm2, ionizing radiation

\section{INTRODUCTION}

Various physical and chemical factors induce DNA lesions, including base damage, intra- and inter-strand cross-linking, and single- and doublestrand breaks (DSBs) (Khanna et al., 2001). DSBs cause remodelling of chromatin and formation of so-called ionizing radiation (IR)-induced foci, where the proteins involved in radiation damage repair are localized within the first minutes after irradiation (Bekker-Jensen et al., 2006). A very early step in the response of mammalian cells to DSBs induced by IR is activation of ATM kinase (Lavin et al., 1995). ATM stands for ataxia-telangiectasia (A-T, a human auto-

\footnotetext{
Corresponding author: A. Tichý, Department of Radiobiology, Faculty of Military Health Sciences in Hradec Králové, University of Defence in Brno, Brno, Czech Republic; phone: (420) 973 253216; fax: (420) 973 253000; e-mail: tichy@pmfhk.cz

$\star$ Preliminary report presented at: The 35th Annual Meeting of the European Radiation Research Society, 22-25 August, 2006, Kiev, Ukraine.

Abbreviations: ATM, ataxia telangiectasia-mutated kinase; Chk-2, checkpoint kinase-2; DSB, double strand break; IR, ionizing radiation; $\mathrm{Mdm} 2$, murine double minute 2 protein; wt, wild type.
} 
somal recessive disorder), whose responsible gene is mutated. ATM, the defective gene in this pleiotropic disease (progressive cerebral ataxia, oculocutaneous telangiectasia, immunodeficiency), encodes a large serine/threonine kinase belonging to the phosphatidylinositol-3 kinase family (Powers et al., 2004). A$\mathrm{T}$ cells exhibit a specific phenotype including increased radiosensitivity, genome instability, cancer predispositions and others (Lavin \& Shiloh, 1997). Cells derived from A-T patients are extremely sensitive to IR, radiomimetic drugs and topoisomerase inhibitors. The importance of ATM is undeniable, since it regulates all three cell cycle checkpoints and functions in the regulation of DNA repair and apoptosis, suggesting that it is a central controller of cellular responses to DSBs (Khanna et al., 2001). Activation of ATM involves rapid intermolecular autophosphorylation of Ser-1981 that causes dissociation of the inactive dimer (Bakkenist \& Kastan, 2003). ATM affects numerous different targets via phosphorylation and some of them participate in the cell cycle arrest. These are p53, murine-double minute protein $(\mathrm{Mdm} 2)$, and checkpoint kinase-2 (Chk-2) in the G1 checkpoint (Canman et al., 1998; Matsuoka et al., 2000; Maya et al., 2001); Nbs1, Brca1, FancD2, and SMC1 in the transient IR-induced S-phase arrest (Taniguchi et al., 2002; Yazdi et al., 2002; Xu et al., 2002); and Brca1 and hRad17 in the G2/M checkpoint (Xu et al., 2001; Bao et al., 2001).

In this work we studied the molecular pathway initiated by IR in MOLT-4 cells. These cells are very radiosensitive; by clonogenic survival assay we determined the $\mathrm{D}_{0}$ value (the dose reducing cell survival to $37 \%$ ) at $0.87 \mathrm{~Gy}$, whereas for the human promyelocyte leukemic cell line HL-60 the $\mathrm{D}_{0}$ is $2.2 \mathrm{~Gy}$ (Vavrova et al., 2004). We investigated mechanisms related to phosphorylation of ATM (Ser-1981) and therefore we studied the phosphorylation of p53 (Ser-392), Chk-2 (Thr-68) and Mdm2 (Ser-166). Here, we report a rapid phosphorylation of ATM and Chk-2 after exposure of cells to IR. We found that protein p53 was induced shortly after activation of ATM and Chk-2. Subsequent phosphorylation of p53 on Ser-392 appeared soon after induction of p53, facilitating its ability to bind to DNA. That was accompanied by concurrent phosphorylation of $\mathrm{Mdm} 2$ on Ser-166, which provides a platform for p53 degradation and decreases its transcriptional activity as part of an auto-regulatory feedback loop.

\section{METHODS}

Cell cultures and culture conditions. MOLT-4 cells were obtained from the American Type Culture Collections (Manassas, VA, USA). The cells were cultured in Iscove's modified Dulbecco's medium (Sig- ma) supplemented with $20 \%$ fetal calf serum, $0.05 \%$ L-glutamine, $150 \mathrm{UI} / \mathrm{ml}$ penicillin, $50 \mu \mathrm{g} / \mathrm{ml}$ streptomycin in a humidified atmosphere with $5 \% \mathrm{CO}_{2}$ at $37^{\circ} \mathrm{C}$. The cultures were split every second day by dilution to a concentration of $2 \times 10^{5}$ cells $/ \mathrm{ml}$. The cell counts were performed with a hemocytometer; the cell membrane integrity was determined by using the Trypan blue exclusion technique. Cell lines at up to 20 passages were used for this study.

Gamma irradiation. Exponentially growing MOLT- 4 cells were suspended at a concentration of $2 \times 10^{5} / \mathrm{ml}$. Aliquots of $10 \mathrm{ml}$ of cell suspension were plated into $25 \mathrm{~cm}^{2}$ flasks (Nunc) and irradiated at room temperature using ${ }^{60} \mathrm{Co}$ gamma-ray source with a dose-rate of $0.4 \mathrm{~Gy} / \mathrm{min}$, at a distance of $1 \mathrm{~m}$ from the source. After the irradiation the flasks were placed in a $37^{\circ} \mathrm{C}$ incubator with $5 \% \mathrm{CO}_{2}$ and aliquots of the cells were removed at various times after irradiation for analysis. The cells were counted and cell viability was determined with the Trypan blue exclusion assay.

Flow-cytometric apoptosis detection. We used APOPTEST-FITC (DakoCytomation, Brno, CZ) for detection of apoptotic cells (annexin V-positive) according to the manufacturer's guide. Analysis was performed on an Epics XL flow-cytometer (Coulter Electronic, Hialeah, FL, USA).

Early apoptotic cells were determined as subG1 cells in DNA content analysis. Following the incubation, $1 \times 10^{4}$ cells were washed with cold PBS (phosphate-buffered saline), fixed with $70 \%$ ethanol and stained with propidium iodide in Vindelov's solution for $30 \mathrm{~min}$ at $37^{\circ} \mathrm{C}$. Fluorescence (DNA content) was measured using the Coulter Electronic apparatus.

Late apoptotic cells were determined by detection of the APO2.7 antigen. The cells were collected and washed twice with cold PBS with 5\% fetal calf serum. Subsequently, $1 \times 10^{5}$ of cells were resuspended in $0.5 \mathrm{ml}$ of PBS with $5 \%$ fetal calf serum and incubated with mouse monoclonal anti-APO2.7 antibody conjugated with phycoerythrin (Beckman Coulter, Fullerton, CA, USA) for $0.5 \mathrm{~h}$ at $4^{\circ} \mathrm{C}$ and measured using the Coulter Electronic apparatus.

In all experiments three independent measurements were performed. Data were analysed using Epics XL System II software (Coulter Electronic).

Electrophoresis and Western blotting. At various times after irradiation, the MOLT-4 cells were washed with PBS and lysed. Whole cell extracts were prepared by lysis in $500 \mu \mathrm{l}$ of lysis buffer $(137 \mathrm{mM} \mathrm{NaCl}, 10 \%$ glycerol, $1 \% n$-octyl$\beta$-glucopyranoside, $50 \mathrm{mM} \mathrm{NaF}, 20 \mathrm{mM}$ Tris/ $\mathrm{HCl}$, $\mathrm{pH}=8,1 \mathrm{mM} \mathrm{Na} \mathrm{VO}_{4}, 1$ tablet of protein inhibitors Complete $^{\mathrm{TM}}$ Mini, Roche). The lysates containing equal amounts of protein $(30 \mu \mathrm{g})$ were loaded onto a $12 \% \mathrm{SDS} /$ polyacrylamide gel. After electrophore- 
sis, proteins were transferred to a PVDF membrane and hybridized with an appropriate antibody (antiATM (Ser-1981), anti-Chk-2 (Thr-68) or anti-Mdm2 (Ser-166) from Upstate, Chicago, IL, USA; anti-p53 or anti-p53 (Ser-392) from Exbio, Prague, CZ; antilamin B from Oncogene, Cambridge, MA, USA). After washing, the blots were incubated with a secondary peroxidase-conjugated antibody (Dako, High Wycombe, UK) and the signal was developed with a chemiluminescence (ECL) detection kit (Boehringer Mannheim) by exposure to an X-ray film (Foma, Hradec Kralove, CZ).

\section{RESULTS}

\section{Induction of apoptosis}

For detection of apoptosis $24 \mathrm{~h}$ after the irradiation we used four different methods: annexin $\mathrm{V}$ binding, DNA content measurement, detection of 7A6 antigen and caspase-catalysed cleavage of lamin B.

The first method uses flow-cytometric detection of annexin $\mathrm{V}$ binding to phosphatidylserine. Exposure of this phospholipid at the plasma membrane is a hallmark of apoptotic process; the method detects both early and late apoptotic cells. After $24 \mathrm{~h}$, $30.7,76.9$, and $94.4 \%$ of cells were apoptotic when irradiated by 1.5, 3.0, and $7.5 \mathrm{~Gy}$, respectively.

For determination of early apoptosis we used flow-cytometric determination of DNA content and so-called sub-G1 peak corresponding to apoptotic cells. After 24 h, 8.8, 15.1 and $18.4 \%$ of cells were apoptotic when irradiated by 1.5, 3.0, and 7.5 Gy, respectively.

For determination of late apoptosis we used flow-cytometric detection of APO2.7 antigen. Since this antigen is localized on the mitochondrial membrane of apoptotic cells, it is possible to perform the assay with permeabilization or without permeabilization, to detect the cells whose plasma membrane is already permeable. To determine cells in the late stage of apoptosis the method without permeabilization was used in this study. After 24 h, 25.5, 66.7, and $91.0 \%$ of cells were apoptotic when irradiated by 1.5, 3.0, and 7.5 Gy, respectively. Figure 1A shows the percentage of annexin V-positive, APO2.7-positive and sub-G1 cells $24 \mathrm{~h}$ after gamma irradiation with increasing doses.

Another method confirming the induction of apoptosis of MOLT-4 cells was Western blot analysis of fragmented nuclear protein lamin B. In non-irradiated cells lamin B is present in the nucleus as a $68-\mathrm{kDa}$ protein. Irradiation causes its cleavage producing a $48-\mathrm{kDa}$ fragment. The data obtained from Western blot analysis indicated that apoptosis was induced within 6 and $16 \mathrm{~h}$, depending on the dose
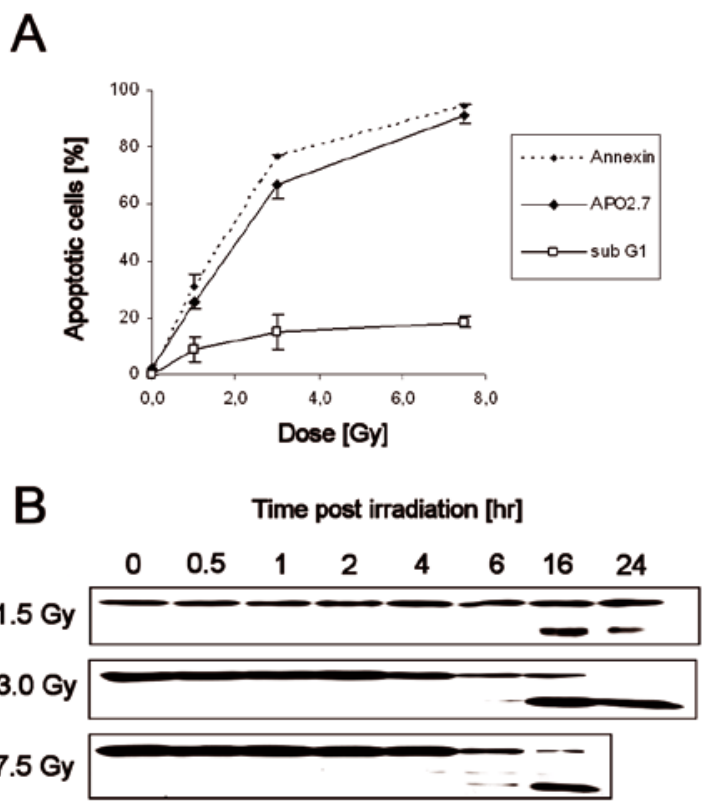

Figure 1. Induction of apoptosis after gamma-irradiation. MOLT-4 cells were irradiated by the doses of 1.5, 3.0, and $7.5 \mathrm{~Gy}$ and apoptosis was determined at the indicated times. A. Flow cytometric detection of apoptotic cells. Annexin V-positive cells were determined by APOPTEST (DakoCytomation), early apoptotic cells were measured as sub-G1 cells of DNA content analysis and late apoptotic cells were determined as APO2.7-positive ones. Each point represents the average of three independent experiments \pm S.E.M. B. Western blots analysis of lamin B. A $68-\mathrm{kDa}$ nuclear protein is cleaved into a $48-\mathrm{kDa}$ fragment when apoptosis is induced. Representative blots are shown.

of IR, since cleaved lamin B was detected $16 \mathrm{~h}$ after $1.5 \mathrm{~Gy}$, and a small amount of the cleaved fragment could also be detected after $6 \mathrm{~h}$ after the doses of 3.0 or $7.5 \mathrm{~Gy}$, respectively (Fig. 1B). Interestingly, after irradiation by the lethal dose of $7.5 \mathrm{~Gy}$ we did not found cleaved lamin B earlier than we did after the sublethal dose of $3.0 \mathrm{~Gy}$, that is after $6 \mathrm{~h}$, although this cleavage was more intense.

\section{Phosphorylation of ATM and Chk-2}

In our experiments on MOLT-4 cells we found an increased amount of phosphorylated ATM (Ser-1981) as soon as $0.5 \mathrm{~h}$ after irradiation. This phosphorylation declined after $6 \mathrm{~h}$ after irradiation by the doses of $1.5 \mathrm{~Gy}, 3.0$ or $7.5 \mathrm{~Gy}$ (Fig. 2A), i.e. just before the time when lamin $\mathrm{B}$ was cleaved and apoptosis was induced. After $0.5 \mathrm{~h}$ there was less active ATM after 1.5 or 3.0 Gy than after 7.5 Gy. Chk-2 was also found to be phosphorylated (Thr68) within $0.5 \mathrm{~h}$, but, unlike for ATM, its amount at that time was not affected by the dose. While the persistence of the phosphorylated form of ATM was the same (up to $6 \mathrm{~h}$ ) after all the doses tested, phos- 

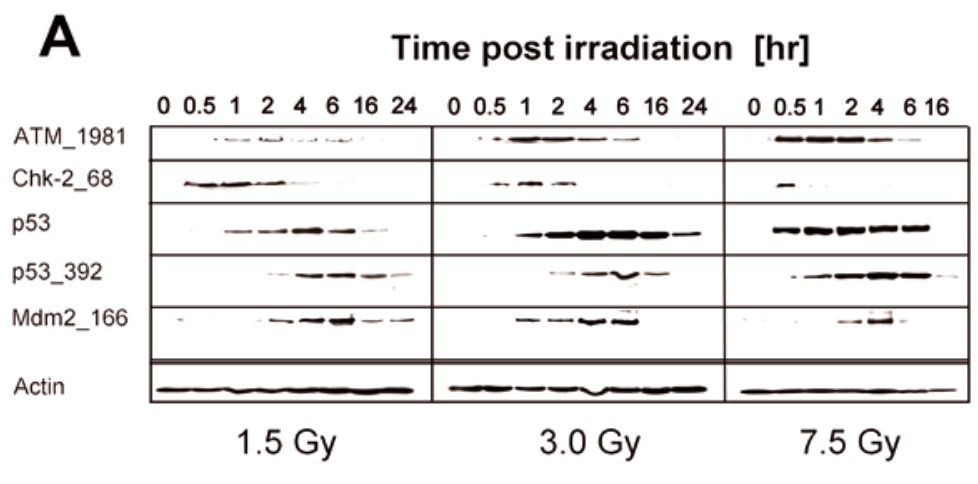

B Dose [Gy]

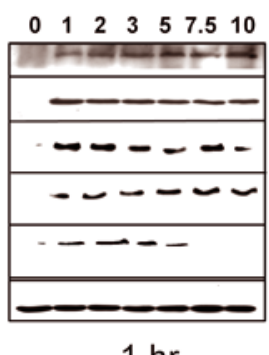

$1 \mathrm{hr}$

Figure 2. Gamma-radiation induced phosphorylation of ATM and its downstream targets.

Representative Western blots are shown. A. MOLT-4 cells were irradiated by the doses of 1.5, 3.0, and 7.5 Gy and analysed at the times as indicated. IR induced rapid phosphorylation of ATM and Chk-2 with subsequent induction and phosphorylation of p53 and concomitant phosphorylation of Mdm2. These processes were followed by induction of apoptosis confirmed by detection of cleavage of lamin B (see Fig. 1B). B. MOLT-4 cells were irradiated by the doses as indicated and analysed $1 \mathrm{~h}$ after irradiation. Neither ATM nor its substrates exhibited a dose-dependent response. Only the amount of phosphorylated Mdm2 at Ser-166 was increased after the exposure to the doses up to 3 Gy, but after the dose of 5 Gy or higher it was decreased.

phorylation of Chk-2 (Thr-68) was detected up to 4,2 , and $1 \mathrm{~h}$ after $1.5,3.0$, and $7.5 \mathrm{~Gy}$, respectively, and it preceded the accumulation of p53 (Fig. 2A). Although the amount of ATM after $0.5 \mathrm{~h}$ appeared to increase with an increasing dose, we did not observe any significant dose-dependence after $1 \mathrm{~h}$ after the exposure to the doses of 1-10 Gy, and also phosphorylation of Chk-2 did not exhibit a dose-dependent response $1 \mathrm{~h}$ post-irradiation (Fig. 2B).

\section{Phosphorylation of $\mathrm{p} 53$}

The p53 protein was up-regulated from 1 up to $16 \mathrm{~h}$ after the dose of $1.5 \mathrm{~Gy}$ with a maximum at $4 \mathrm{~h}$. After the dose of $3.0 \mathrm{~Gy}$ the up-regulation of p53 was detectable from 1 to $24 \mathrm{~h}$ and it was more intense, with a maximum also at $4 \mathrm{~h}$. The dose of $7.5 \mathrm{~Gy}$ induced p53 very rapidly and transiently (from 0.5 to $6 \mathrm{~h}$ ) with a maximum within 1-2 $\mathrm{h}$ after irradiation (Fig. 2A). p53 was subsequently phosphorylated on Ser-392 beginning $2 \mathrm{~h}$ after the dose of 1.5 and $3.0 \mathrm{~Gy}$, or $0.5 \mathrm{~h}$ after $7.5 \mathrm{~Gy}$. The phosphorylation on Ser-392 persisted up to $16 \mathrm{~h}$ after irradiation by 1.5 and 3.0 Gy. After $7.5 \mathrm{~Gy}$ it declined after $6 \mathrm{~h}$.

At the time of maximal phosphorylation of p53 we observed an increase in phosphorylated oncoprotein Mdm2 (Ser-166), i.e. from 4 to $6 \mathrm{~h}$ after the dose of 1.5 or $3.0 \mathrm{~Gy}$, or from 2 to $4 \mathrm{~h}$ after $7.5 \mathrm{~Gy}$ (Fig. 2A).

Similarly to ATM and Chk-2, neither induction of p53 nor its phosphorylation on Ser-392 exhibited a dose-dependent response $1 \mathrm{~h}$ after the exposure to the doses of 1 to $10 \mathrm{~Gy}$ (Fig. 2B). All proteins analysed were up-regulated after $1 \mathrm{~h}$ after gamma irradiation, nevertheless none of them but Mdm2 exhibited a dose-dependent response. One hour after the exposure to doses up to $3 \mathrm{~Gy}$ the amount of Mdm2 phosphorylated on Ser-166 increased, however, after the dose of $5 \mathrm{~Gy}$ or higher we observed a decrease in Mdm2 phosphorylation (Fig. 2B), suggesting that not even this protein might be exploited as a biodosimetric indicator.

\section{DISCUSSION}

MOLT-4 cells are derived from human T-cell leukemia, with immunophenotypic characteristics of thymocytes, expressing $\mathrm{CD}^{+}(49 \%), \mathrm{CD}^{+}(55 \%)$, $\mathrm{CD}^{+}(72 \%)$, and $\mathrm{CD}^{+}(77 \%)$ (Greenberg et al., 1988) and they are a suitable model system to study molecular mechanisms of gamma-radiation-induced apoptosis of T-lymphocytes. Work on p53-null mice has revealed that p53 protein is important for induction of apoptosis as a response of T-lymphocytes to DNA damage (Clarke et al., 1993). Our results together with the work of other authors (Nakano \& Shinohara, 1999; Nakano et al., 2001) prove that in MOLT-4 cells accumulation of p53 precedes typical apoptotic changes, such as fragmentation of DNA (sub-G1 peak), changes in plasma membrane phospholipids (annexin V), loss of plasma membrane integrity and mitochondrial changes (APO2.7), and cleavage of nuclear structural proteins (lamin B).

Induction of apoptosis in MOLT-4 cells (p53 wt) after exposure to doses up to $10 \mathrm{~Gy}$ is faster than in HL-60 cells (promyelocytic leukemia, p53null). MOLT-4 cells show a wide disparity in the time when apoptosis is induced after gamma irradiation. The cells die mostly by delayed apoptosis and by post-mitotic apoptosis. The results of our previ- 
ous work show that the sub-G1 peak is not induced before $6 \mathrm{~h}$ after irradiation by doses up to $5 \mathrm{~Gy}$. The cells accumulate mainly in $S$ phase and less in G2 phase (not shown).

Figure 1A compares the percentage of apoptosis determined by three methods $24 \mathrm{~h}$ after irradiation - annexin V-positive, APO2.7-positive (without permeabilization) and sub-G1 cells. A comparison of these methods indicates that determination of annexin V-positive and APO2.7-positive cells shows approximately the same results (thus, $24 \mathrm{~h}$ after irradiation the plasma membrane of the majority of apoptotic cells was permeable). The third method, determination of sub-G1 cells, provides much different data. After the doses of 3.0 and 7.5 Gy we determined roughly the same fraction of early apoptotic cells, $15.1 \%$ and $18.4 \%$, respectively. It seems that MOLT-4 cells quickly form apoptotic bodies, decompose and the flow-cytometer evaluates the resulting fragments as debris.

After $24 \mathrm{~h}$ almost all the cells irradiated by the dose of 7.5 Gy were APO2.7-positive (without permeabilization), their plasma membrane was permeable at that time and they were apoptotic. Endlich et al. (2000) reported that only $24 \%$ of MOLT- 4 cells underwent apoptosis without attempting cell division after a dose of $4 \mathrm{~Gy}$. Most of the cells did not die until 18 to $30 \mathrm{~h}$, however, mitosis either failed or the division was aberrant. We noticed the beginning of apoptosis (according to cleavage of nuclear lamin B) $16 \mathrm{~h}$ after $1.5 \mathrm{~Gy}$ and after $6 \mathrm{~h}$ after 3.0 or $7.5 \mathrm{~Gy}$, respectively. Endlich et al. (2000) observed that the apoptotic death process ended by formation of apoptotic bodies 36 to $60 \mathrm{~h}$ post-irradiation.

To date, the proteins that directly sense DNA damage in mammalian cells are largely unidentified and the mechanism by which these sensors transmit DNA damage recognition to ATM remains to be elucidated. Bakkenist and Kastan (2003) in their work on fibroblasts suggested that introduction of DSB causes a rapid change of a higher-order chromatin structure, and that this chromatin alteration initiates ATM activation. ATM responds primarily to DSB, whilst other forms of DNA damage, such as UV radiation-induced photoproducts and replication fork stalling signal through the ATM- and Rad3-related (ATR) kinases. Recent studies have demonstrated that ATM functions upstream of ATR following exposure to IR in S/G2 (Stiff et al., 2006) and they both exhibit selective substrate specificity in response to different genotoxic agents (Helt et al., 2005). In addition, Bekker-Jensen et al. (2006) have reported that ATM is spatially redistributed to DSB-flanking chromatin and ATR accumulates by single-stranded DNA. Two other kinases, Chk-1 and Chk-2, do not concentrate around the DNA damage sites but rapidly spread to the entire nucleus. Chk-1 and Chk-2 are structurally unrelated yet functionally overlapping serine/threonine kinases. Chk- 1 is a labile protein, active even in unperturbed cell cycles, since it plays an important role in keeping Cdc25C prepared for responding to DNA damage by phosphorylating its Ser-216 during the $S$ to $M$ phase (Kaneko et al., 1999; Zhao et al., 2002). In contrast, Lukas et al. (2001) showed that Chk-2 is a relatively stable protein responding to gamma-radiation throughout the cell cycle and it appears to be inactive in the absence of DNA damage. Nevertheless, recent findings of specific target knockdowns (Xiao et al., 2006) suggest that Chk-1 is the only checkpoint kinase relevant as a cancer drug target. Our study shows that MOLT4 cells, having wt p53, exhibit the same response to gamma-irradiation as fibroblasts do, i.e. they phosphorylate ATM and Chk-2 quickly after irradiation.

We found ATM to be phosphorylated early after irradiation and this phosphorylation persisted $6 \mathrm{~h}$. Later (after irradiation by all the doses tested) the amount of ATM decreased. This was due to the fact that ATM is degraded before DNA fragmentation in the later stages of apoptosis resulting in the predominance of DNA-dependent protein kinase (DNA-PK). This is consistent with the results of Mukherjee et al. (2006), who proved that H2A.X (one of the core histones phosphorylated by ATM within the first minutes after irradiation) is phosphorylated in the later stages of apoptosis solely by DNA-PK, while ATM is dispensable for this process. Matsuoka et al. (2000) showed on fibroblasts that phosphorylated ATM subsequently phosphorylates Chk-2 on Thr-68. Here we show that after $0.5 \mathrm{~h}$ the amount of active ATM after 1.5 or 3.0 Gy was significantly less than after 7.5 Gy, nevertheless, even that amount was sufficient to activate Chk-2, which was phosphorylated within $0.5 \mathrm{~h}$ too.

Exposure to IR causes damage to DNA in the form of DSBs. This immediately activates ATM, which is involved in the cell cycle regulation and DNA repair and further conducts the signal up to p53 protein. It is well known that p53 possesses protective functions, such as stimulation of nucleotide excision repair and induction of cell cycle arrest (via other gene products) that is needed in order to check and repair the DNA damage. In contrast to these protective properties, p53 has also been implicated in the induction of apoptosis in certain cell types following DNA damage (reviewed in Ljungman, 2000). Work of Nakano et al. (2001) and our previous work (Szkanderova et al., 2003) showed the radiation-induced apoptosis in MOLT-4 cells to be fully p53-dependent.

Both ATM and Chk-2 contribute to the precise control of an important element of the cellular emergency team, the p53 protein. Acting as a transcription factor for a number of downstream genes 
that mediate either cell cycle arrest or apoptosis, p53 plays a critical role in maintaining genomic integrity after cellular stress by preventing propagation of damaged DNA. Nakano et al. (1999) and Szkanderova et al. (2003) suggested that the level of p53 must reach a threshold for the cells to undergo apoptosis.

Protein p53 was up-regulated after $1 \mathrm{~h}$ after irradiation by the cytostatic or the sublethal dose (1.5 and 3.0 Gy). The lethal dose (7.5 Gy) induced upregulation of p53 very quickly (within $0.5 \mathrm{~h}$, which was the time of activation of ATM and Chk-2). This rapidity reflects the emergency state in the cell after a large DNA insult and the need to urgently induce enough p53 to stop the cell cycle and to try to repair the damage or induce apoptosis.

But the up-regulated p53 does not function properly until post-translationally modified. The carboxyl terminus of p53 functions as an allosteric regulator. Phosphorylations on Ser-315 and Ser-392 localized within this domain enhance its sequencespecific DNA binding (Criswell et al., 2003). Casein kinase 2 (CK2) phosphorylates p53 on Ser-392, but Claudio et al. (2006) demonstrated that Cdk9 itself is capable of such phosphorylation independently of CK2. Sakaguchi et al. (1997) showed that phosphorylation of Ser-392 stabilizes the tetramer formation of p53 that is critical for p53's ability to activate transcription because it facilitates phosphorylation of the transactivation domain due to a more favourable conformation. In this study, we also demonstrated that p53 was phosphorylated on Ser-392 and this phosphorylated form persisted $16 \mathrm{~h}$ after the cytostatic or the sublethal dose and $6 \mathrm{~h}$ after the lethal one. We showed in our previous work (Szkanderova et al., 2003) that IR causes in MOLT-4 cells also phosphorylation on Ser-15 and both phosphorylations on Ser3-92 and on Ser-15 show similar temporal patterns (they both decline after $6 \mathrm{~h}$ ).

Whilst Bekker-Jensen et al. (2006) showed that U2OS human osteosarcoma cells treated with a DSBgenerating insult (1-10 Gy) respond after $1 \mathrm{~h}$ by a homogeneous increase of phosphorylated p53 (Ser15) throughout the entire nucleus, our experiments revealed no dose-dependent response of phosphorylation of p53 (Ser-392) $1 \mathrm{~h}$ after the exposure to the doses of 1 to 10 Gy (Fig. 2B).

Our results indicate that molecules involved in downstream pathways activated by ATM rather than ATM itself and its direct downstream targets would be suitable for biodosimetry in practice. ATM and its substrates might be used only in the low dose-range, although for reliable biodosimetry not a single one, but several biological indicators of the absorbed dose should be exploited.

We proved that MOLT-4 cells (p53 wt) respond to the IR-induced damage by phosphorylation of ATM and Chk-2 (within $0.5 \mathrm{~h}$ after irradiation). We also proved that phosphorylation of p53 protein ( $2 \mathrm{~h}$ after irradiation) is accompanied by phosphorylation of its negative regulator, $\mathrm{Mdm} 2$ protein, which occurs concomitantly with maximal p53 phosphorylation.

\section{Acknowledgement}

The authors thank the Ministry of Defence of the Czech Republic for financial support (projects MO0FVZ0000501 and OBUKHK2005001).

\section{REFERENCES}

Bao S, Tibbetts RS, Brumbaugh KM, Fang Y, Richardson DA, Ali A, Chen SM, Abraham RT, Wang XF (2001) ATR/ATM-mediated phosphorylation of human Rad17 is required for genotoxic stress responses. Nature 411: 969-974.

Bakkenist C, Kastan MB (2003) DNA damage activates ATM through intermolecular autophosphorylation and dimmer dissociation. Nature 421: 499-506.

Bekker-Jensen S, Lukas C, Kitagawa R, Melander F, Kastan MB, Bartek J, Lukas J (2006) Spatial organization of the mammalian genome surveillance machinery in response to DNA strand breaks. J Cell Biol 173: 195-206.

Canman CE, Lim DS, Cimprich KA, Taya Y, Tamai K, Sakaguchi K, Appella E, Kastan MB, Siliciano JD (1998) Activation of the ATM kinase by ionizing radiation and phosphorylation of p53. Science 281: 1677-1679.

Clarke AR, Purdie CA, Harrison DJ, Morris RG, Bird CC, Hooper ML, Wyllie AH (1993) Thymocyte apoptosis induced by p53-dependent and independent pathways. Nature 6423: 849-852.

Claudio PP, Cui J, Ghafouri M, Mariano C, White MK, Safak M, Sheffield JB, Giordano A, Khalili K, Amini S, Sawaya BE (2006) Cdk9 phosphorylates p53 on serine 392 independently of CKII. J Cell Physiol 208: 602-612.

Criswell T, Leskov K, Miyamoto S, Luo G, Boothman DA (2003) Transcription factors activated in mammalian cells after clinically relevant doses of ionizing radiation. Oncogene 22: 5813-5827.

Endlich B, Radford IR, Forrester HB, Dewey WC (2000) Computerized video time-lapse microscopy studies of ionizing radiation-induced rapid-interphase and mitosis-related apoptosis in lymphoid cells. Radiat Res $\mathbf{1}$ : 36-48.

Greenberg JM, Gonzalez-Sarmiento R, Arthur DC, Wilkowski CW, Streifel BJ, Kersey JH (1988) Immunophenotypic and cytogenetic analysis of Molt-3 and Molt-4: human T-lymphoid cell lines with rearrangement of chromosome 7. Blood 5: 1755-1760.

Helt CE, Cliby WA, Keng PC, Bambara RA, O'Reilly MA (2005) Ataxia telangiectasia mutated (ATM) and ATM and Rad3-related protein exhibit selective target specificities in response to different forms of DNA damage. $J$ Biol Chem 280: 1186-1192.

Honda R, Tanaka H, Yasuda H (1997) Oncoprotein MDM2 is a ubiquitin ligase E3 for tumor suppressor p53. FEBS Lett 420: 25-27.

Kaneko YS, Watanabe N, Morisaki H, Akita H, Fujimoto A, Tominaga K, Terasawa M, Tachibana A, Ikeda K, Nakanishi M (1999) Cell-cycle-dependent and ATM-in- 
dependent expression of human Chk1 kinase. Oncogene 18: 3673-3681.

Khanna KK, Lavin MF, Jackson SP, Mulhern TD (2001) ATM, a central controller of cellular responses to DNA damage. Cell Death Diff 8: 1052-1065.

Khosravi R, Maya R, Gottlieb T, Oren M, Shiloh Y, Shkedy D (1999) Rapid ATM-dependent phosphorylation of MDM2 precedes p53 accumulation in response to DNA damage. Proc Natl Acad Sci USA 96: 14973-14977.

Kim ST, Lim DS, Canman, CE, Kastan MB (1999) Substrate specificities and identification of putative substrates of ATM kinase family members. J Biol Chem 274: 37538 37543.

Lavin MF, Shiloh Y (1997) The genetic defect in ataxia-telangiectasia. Annu Rev Immunol 15:177-202.

Lavin MF, Khanna KK, Beamish H, Spring K, Watters D, Shiloh Y (1995) Relationship of the ataxia-telangiectasia protein ATM to phosphoinositide 3-kinase. Trends Bioch Sci 20: 382-383.

Ljungman M (2000) Dial 9-1-1 for p53: mechanisms of p53 activation by cellular stress. Neoplasia 2: 208-225.

Lim DS, Kim ST, Xu B, Maser RS, Lin J, Petrini JH, Kastan MB (2000) ATM phosphorylates p95/nbs1 in an S-phase checkpoint pathway. Nature 404: 613-617.

Lukas C, Bartkova J, Latella L, Falck J, Mailand N, Schroeder T, Sehested M, Lukas J, Bartek J (2001) DNA damage-activated kinase Chk2 is independent of proliferation or differentiation yet correlates with tissue biology. Cancer Res 61: 4990-4993.

Matsuoka S, Rotman G, Ogawa A, Shiloh Y, Tamai K, Elledge SJ (2000) Ataxia telangiectasia-mutated phosphorylates Chk2 in vivo and in vitro. Proc Natl Acad Sci USA 97: 10389-10394.

Maya R, Balass M, Kim ST, Shkedy D, Leal JF, Shifman O, Moas M, Buschmann T, Ronai Z, Shiloh Y, Kastan MB, Katzir E, Oren M (2001) ATM-dependent phosphorylation of Mdm2 on serine 395: Role in p53 activation by DNA damage. Genes Dev 15: 1067-1077.

Mukherjee B, Kessinger C, Kobayashi J, Chen BP, Chen DJ, Chatterjee A, Burma S (2006) DNA-PK phosphorylates histone $\mathrm{H} 2 \mathrm{AX}$ during apoptotic DNA fragmentation in mammalian cells. DNA Repair 5: 575-590.

Nakano H, Shinohara K (1999) Correlation between unirradiated cell TP53 protein levels and radiosensitivity in MOLT-4 cells. Radiat Res 151: 686-693.

Nakano H, Kohara M, Shinohara K (2001) Evaluation of the relative contribution of p53-mediated pathway in X-ray-induced apoptosis in human leukemic MOLT-4 cells by transfection with a mutant $\mathrm{p} 53$ gene at different expression levels. Cell Tissue Res 306: 101-106.
Powers JT, Hong S, Mayhew CN, Rogers PM, Knudsen ES, Johnson DG (2004) E2F1 uses the ATM signaling pathway to induce p53 and Chk2 phosphorylation and apoptosis. Mol Cancer Res 4: 203-214.

Sakaguchi K, Sakamoto H, Lewis MS, Anderson CW, Erickson JW, Appella E, Xie D (1997) Phosphorylation of serine 392 stabilizes the tetramer formation of tumor suppressor protein p53. Biochemistry 36: 10117-10124.

Stiff T, Walker SA, Cerosaletti K, Goodarzi AA, Petermann E, Concannon P, O'driscoll M, Jeggo PA (2006) ATRdependent phosphorylation and activation of ATM in response to UV treatment or replication fork stalling. EMBO J 25: 5775-5782.

Szkanderova S, Vavrova J, Rezacova M, Vokurkova D, Pavlova S, Smardova J, Stulik J (2003) Gamma irradiation results in phosphorylation of p53 at serine-392 in human T-lymphocyte leukaemia cell line MOLT-4. Folia Biol (Prague) 49: 191-196.

Taniguchi T, Garcia-Higuera I, Xu B, Andreassen PR, Gregory RC, Kim ST, Lane WS, Kastan MB, D'Andrea AD (2002) Convergence of the Fanconi anemia and Ataxia telangiectasia signaling pathways. Cell 109: 459-472.

Vavrova J, Rezacova M, Vokurkova D, Psutka J (2004) Cell cycle alteration, apoptosis and response of leukemic cell lines to gamma radiation with high- and low-dose rate. Physiol Res 53: 335-342.

Yazdi PT, Wang Y, Zhao S, Patel N, Lee EY, Qin J (2002) SMC1 is a downstream effector in the ATM/NBS1 branch of the human S-phase checkpoint. Genes Dev 16: 571-582.

Xiao Z, Xue J, Sowin TJ, Zhang H (2006) Differential roles of checkpoint kinase 1, checkpoint kinase 2, and mitogen-activated protein kinase-activated protein kinase 2 in mediating DNA damage-induced cell cycle arrest: implications for cancer therapy. Mol Cancer Ther 8: 1935-1943.

Xu B, Kim ST, Kastan MB (2001) Involvement of Brca1 in S-phase and G2-phase checkpoints after ionizing irradiation. Mol Cell Biol 21: 3445-3450.

Xu B, O’Donnell AM, Kim ST, Kastan MB (2002) Phosphorylation of serine 1387 in Brca1 is specifically required for the Atm-mediated S-phase checkpoint after ionizing irradiation. Cancer Res 62: 4588-4591.

Zhao H, Watkins JL, Piwnica-Worms H (2002) Disruption of the checkpoint kinase $1 /$ cell division cycle $25 \mathrm{~A}$ pathway abrogates ionizing radiation-induced S and G2 checkpoints. Proc Natl Acad Sci USA 99: 14795-14800. 